\title{
IMPLEMENTATION OF 'VILLAGEFAMILY PLANNING ' PROGRAM IN RPTRA CIRACAS PRIMA, EAST JAKARTA
}

\author{
Okta Zenita Siti Fatimah ${ }^{1)}$, Dewi Suri damayanti ${ }^{2)}$ \\ Email :okta.zenita@gmail.com \\ ${ }^{1,2)}$ Prodi D3 Kebidanan Universitas Mohammad Husni Thamrin \\ Jl. Raya Pondok Gede Kramat Jati Jakarta Timur
}

\section{Article Information}

Received:

September 24, 2019

Revised:

December 26, 2019

\section{Accepted:}

January 19, 2020

Available online:

January 23, 2020

\begin{abstract}
Some women did not know when they could get pregnant again. Choices in birth planning are very influential in preventing complications. This study was based on the launching of the Village family planning in RPTRA Ciracas Prima. The purpose of this study was to describe the implementation of the Village family planning in RPTRA Ciracas Prima.This study was qualitative with descriptive method - data collected by an indepth interview by following the guidelines. The information obtained was recorded and made in the form of field notes a model on Policy Implementation developed by George C. Edward III.The results showed that the program in RPTRA Ciracas Prima based on four implementation indicators discovered that in communication, the transmission was carried out with an effort to socialize its clarity, which was not yet fully understood by the public. The bureaucratic structure and targets should be optimized. RPTRA had inadequate facility resources like a limited corridor, and particular medical space was incomplete. However, the last indicators showed from the optimization of cadre effort implementing the village family planning program. Population growth significantly increases know from the number of acceptors of long-acting reversible contraception. In the implementation of facilities and infrastructure such as Pos village family planning, it should be devoted to activities related to family planning. BKKBN must be able to motivate the community so that they can participate in the implementation of the village family planning program in RPTRA Ciracas Prima.
\end{abstract}

Keyword: implementation, village family planning

\section{Introduction}

According to BKKBN in Jakarta 2014, Family Planning Village is a regional unit at the level of RW or village that has criteria; there was an integration of the Population, Family Planning and Family Establishment program or known as KKBPK. Furthermore, there was an establishment in several related sectors which are carried out systematically. The Family Planning Village launched first by Joko Widodo (President of Indonesia) in
Cirebon Regency, West Java on January 14th, 2016. The Family Planning Village was also designed to integrate various population, family planning and family establishment programs with cross-sector development programs to create small families with quality, and increasing the number of active family planning participants with the long-acting reversible contraception (LARC's). ${ }^{[1]}$ 
East Jakarta Administration Government officially opened ten Villages family planning. The inauguration was held symbolically at RPTRA Citra Permata, Jatinegara, and Rawa Bunga. The declaration of the Village family planning in East Jakarta indicates that there was participation from the community and was determined by decree letter from East Jakarta City Government. Village family planning did not only carry out the KKBPK program but also infrastructure, social, economic, housing, education, culture and others. Data from BKKBN of East Jakarta City in 2016, Village family planning that has been established in East Jakarta were RPTRA Utakose, South Utan Kayu subdistrict, RPTRA Citra Permata, Rawa Bunga sub-district, RPTRA Jati Bersinar, Jati sub-district, RPTRA Muara Condet, Batu Ampar sub-district, RPTRA Rawa Jaya, Pondok Kopi sub-district, RPTRA Kampung Pulo Berseri, Pinang Ranti subdistrict, RPTRA Kocapiring, Pekayon sub-district, RPTRA Pulo Gebang Permai, Pulo Gebang sub-district, RPTRA Payung Tuntas, Cipayung subdistrict and RPTRA Ciracas Prima, Ciracas sub-district.

Ciracas is one of sub-district in Ciracas District, East Jakarta with an area of $27.4 \mathrm{~km}$. Based on data from the Ciracas Community Health Center in Ciracas Sub-district in 2015, there were 5,554 pregnant women, and $90.1 \%$ of them had their examination.

Table 1 Data of Pregnant Mothers in Ciracas District in 2015

\begin{tabular}{llcc}
\hline No & $\begin{array}{l}\text { Sub- } \\
\text { district }\end{array}$ & $\begin{array}{c}\text { Pregnant } \\
\text { mothers }\end{array}$ & $\begin{array}{c}\text { Controlled } \\
\text { Pregnancies }\end{array}$ \\
\hline 1 & Rambutan & 798 & 799 \\
2 & Susukan & 915 & 915 \\
3 & Ciracas & 1448 & 1182 \\
4 & Kelapa Dua & 991 & 953 \\
& Wetan & & \\
6 & Cibubur & 1461 & 1153 \\
& Total & 5554 & 5002 \\
\hline
\end{tabular}

Source: Ciracas Health Center Data in 2015

The number of controlled pregnancies in Ciracas sub-district was the highest compared to other subdistricts.

Pregnancy is a blessed for women, their husband and family members. However, there were conditions where pregnant women were found to had a high risk, thus threatening the health of the mother and the baby. Conditions of pregnancy can be risky if pregnant women are found in '4 Too' condition or known as 4T. According to data from the Ministry of Health (2011), there were $65 \%$ of pregnant women experience one or more of the 4T criteria. This condition can increase the risk of complications in the mother or the baby during pregnancy and childbirth. The effort to increase the number of villages family planning was one of the government's strategies in overcoming the $4 \mathrm{~T}$ problem. The establishment of several villages family planning aims to make it easier for the community to reach out to consultations or counselling on how to use contraceptives and find out its benefits. ${ }^{[2]}$ Ideally, the community in village family planning should participate in the whole program. However, in reality, the level of activity of Ciracas residents to be active participants was still lacking, other than that there was no control and evaluation from the government. Zuhriyah (2017) evaluating the implementation of the village family planning stated that the village family planning was not active yet in improving family planning program reviewed from three aspects, i.e. input, process, and output. The village family planning program aims to keep pregnancy apart and provide benefits to the physical and psychological health of the mother and the baby. Another benefit is that it can improve the quality of mother-child relationships which in turn will affect the quality of children. The program will undoubtedly provide time for the father to prepare for economic needs. The rate of population growth would be out of control if there were no village family planning program. Another risk is an increase in high-risk pregnancies - for example, pregnancy with old age, a distance that is 
too close, and teenage pregnancy. Referring to the official data, $5-10 \%$ of pregnancies were high-risk. ${ }^{[3]}$ This study aims to describe and analyze how the implementation of the village family planning program and identify obstacles in the implementation in RPTRA Ciracas Prima, East Jakarta.

\section{Method}

This study was qualitative. Location of this study was in Ciracas sub-district and BKKBN Ciracas. Key informant in this study was the head of family health. The key informants were directing in finding the main informant for this study and obtained village officer, secretary of ciracas sub-district and cadres. Sampling technique in this study used purposive sampling. The triangulation informants in this study were community representative.

Data collected through in-depth interview following the guidelines and assisted using a recorder and a field note. The data further analyzed using source triangulation by cross-checking the data from key informants and main informants with informants triangulation.

\section{Result and Discussion}

a. Resources

Resources in the village family planning program consist of facility resources, implementers, and funds.

"Funds resources were from nongovernmental organizations, APBD, APBN, Companies (CSR). The authority came from the head of subdistrict to PLKB. That facility was not optimally used because RPTRA was still in a limited corridor and also there did not have a particular room for medical treatment" (IU. 1)

"It was enough, even though if human resources were added, we will be happier to get more help. Because when one of the implementers was absent, we were shorthanded. So far, we can overcome this for the sake of running the program. The funds were sufficient; the only facilities available was contraceptions in the health centre or places to carry out family planning activities like posyandu. Sometimes the activity held in willing resident or at mosque or PLKB" (IU.2)

"Human resources in the implementation of village family program were enough already. Also, support from religious and community leaders as well as from village officials was sufficient"(IU.3)

"more resources would be faster to accomplished; there was not any problem with funding so far" (IU. 4)

Based on the interview result, the detailed findings of this study can be seen in Table 2.

Table 2 Research Findings on Resources

\begin{tabular}{|c|c|c|}
\hline Indicators & Implementation & Impact \\
\hline $\begin{array}{l}\text { Human } \\
\text { Resources }\end{array}$ & $\begin{array}{l}\text { Enough, funds } \\
\text { resources were } \\
\text { from non- } \\
\text { governmental } \\
\text { organizations, } \\
\text { APBN, APBD, and } \\
\text { CSR. The } \\
\text { authority of the } \\
\text { sub-district office } \\
\text { instructed to the } \\
\text { head of the PLKB. }\end{array}$ & $\begin{array}{l}\text { The program } \\
\text { aimed to } \\
\text { maintain the } \\
\text { distance of } \\
\text { pregnancy, the } \\
\text { quality of the nest } \\
\text { generation, and } \\
\text { increasing quality } \\
\text { of mother and } \\
\text { child } \\
\text { relationship. }\end{array}$ \\
\hline $\begin{array}{l}\text { Funds } \\
\text { Resources }\end{array}$ & Enough & $\begin{array}{l}\text { Able to meet the } \\
\text { needs related to } \\
\text { funds in the } \\
\text { family planning } \\
\text { village program. }\end{array}$ \\
\hline $\begin{array}{l}\text { Facilities } \\
\text { Resources }\end{array}$ & $\begin{array}{l}\text { The facility was } \\
\text { not optimal yet } \\
\text { because RPTRA } \\
\text { was still in a } \\
\text { limited corridor } \\
\text { and also some } \\
\text { particular room } \\
\text { for medical } \\
\text { treatments was } \\
\text { not complete. }\end{array}$ & $\begin{array}{l}\text { Succeed and } \\
\text { accelerating the } \\
\text { process of } \\
\text { activities to fit the } \\
\text { initial goals of } \\
\text { implementation } \\
\text { for the } \\
\text { achievement of } \\
\text { children's quality. }\end{array}$ \\
\hline
\end{tabular}

Sources: Data Analysis

From the interview results, it is known that the resources in the village family planning were following the theories of Edward III and Van Meter and Van Horn which state that resources have a significant effect on the policy implementation process. 
Human resources (numbers and competencies), physical resources (facilities), information resources and authority resources. Other resources were also essential in the successful implementation of the policy, which was a sufficient amount of funding resources and also an appropriate use of time and needs. ${ }^{[4]}$

b. Bureaucratic Structure

Another essential aspect of the implementation of village family planning is the bureaucratic structure. In this structure, there were operational standards for the implementation of the village family planning program.

"The SOP used as a guideline for implementing the village family planning in which the division of tasks carried out by the Health Department, Sub-district Office, PLKB and cadres.Moreover, it was in line with expectations. Usually, they held a meeting every month, coordinating meetings with related agencies which supporting their program it was being held every month also too; socialization every week followed by monitoring and evaluation and finally reporting” (IU. 1)

"For implementation standards or Standard Operating Procedures (SOP) the family planning program itself is a technical manual for the implementation of the village family planning as a guide for implementers in implementing this program. From the beginning of the activity to the final stage, namely the report and program evaluation, all follow the technical manual" (IU. 2)

"Standard Operating Procedure (SOP) for family planning programs used technical manuals for the implementation of the village family planning as a guide" (IU. 3)

"there was an SOP book that regulates ma'am" (IU. 4)

The bureaucratic structure was the part that has tasked in implementing policies which in its implementation require standard operating procedures (SOP). By using SOP, the implementers can optimize the time available and be able to function in following the rules. ${ }^{[5]}$ The SOP uses technical guidelines as a guideline for the implementation of family planning villages where the division of roles is carried out by the Health Office, PLKB, sub-district office and cadres. The bureaucratic structure in the implementation of the village family planning program to include a part of the program implementing organization. Each part of the implementer has different functions and responsibilities following the agreed guidelines for implementing the $\mathrm{KB}$ village program. ${ }^{[6]}$ Differences in functions and tasks among the various implementing elements were aggregated into precise and efficient coordination. Coordination is needed to create the right conditions of cooperation and harmony between the various parties implementing the program so that the implementation of the program can run towards the intended goal. ${ }^{[7]}$

c. Communication

Communication is another essential aspect of implementing villages family planning. In communication itself, several aspects must be considered, such as communication distribution, consistency, and clarity of communication. Communication has an essential role in the ongoing coordination in the implementation of a policy. Communication is the process of coordination and integration of various functions that exist in each part of the structure of the implementation of the policy. Communication needed to get $\mathrm{f}$ the implementers to be following the provisions and objectives of the policy. ${ }^{[8]}$

"From my understanding, the implementation was quite good, as evidenced by the population growth 
that was quite good compared to the last year. The objectives were also evident. The schedule has been arranged by the PLKB, which intersects with the RPTRA and its surroundings. This RPTRA was only a forum for the village family planning, but actually, the entire Ciracas village could be called as village family planning, but, the activities were centred in the RPTRA, because from its location, it may be more elegant in explaining the materials to be more precise. The consistency is shown from activities every month following Posbindu or posyandu schedule" (IU. 1)

"Communication and coordination were going well. We always try to coordinate with related parties in the implementation of the village family planning program. They provide information from the village family planning program to PLKB, cadres, religious leaders, and community leaders. Moreover, for communication with residents, we have done it through socialization related to village family planning using either print media, billboards or invitations to socialization activities" (IU. 2)

"Communication and coordination were excellent, ma'am. If there were an activity, it would be directly discussed in the meeting" (IU. 3)

"Previously, the sub-district office conducted counselling about IUD, implants, and condoms; then the head of the PLKB instructed cadres. The task of the cadres was to look for acceptors or announce to those who had not used contraception. In my opinion, the communication made between the implementing staff was quite clear and consistent by using several communication media such as, official notification letters, meetings that were followed by all implementing staff which were held regularly at PLKB" (IU. 4)

The aspect of communication, in particular, the provision of information to the public, did not yet cover the entire community. Not all residents understood, only a few did. Communication between the implementing officer and the community as the target of the family planning program was more likely to be in the form of direct communication without appropriate socialization or counselling. The process usually takes the form of program notification directly to contraceptive acceptors in Ciracas Prima RPTRA. That was why some residents did not understand about the program.

"There were no socialization programs, let alone whats program about, I had never heard of it" (IT. 1) "Activities in RPTRA were like regular meetings held inPosyandu" (IT. 2)

"the socialization seems to be included if there are activities in the community" (IT. 4)

"my understanding, socialization of the family planning village has not been carried out" (IT. 5)

Nevertheless, there seems to be an increase in knowledge in the community. Some socialization activities were carried out in particular to increase knowledge about contraception.

"RPTRA for family planning counselling, if I'm not mistaken, usually the socialization was through activities in community activities such as posyandu, recitation, or other activities. We came to understand about contraception. I used to know that contraception was only injection and pill, but now I know that there were an IUD and implant" (IT. 4)

Based on the explanation above, the detailed findings of this study can be seen in Table 3 .

Table

3 ResearchFindings on Communication 


\begin{tabular}{|c|c|c|}
\hline Indicators & Implementation & Impact \\
\hline $\begin{array}{l}\text { Communic } \\
\text { ation } \\
\text { Media }\end{array}$ & $\begin{array}{l}\text { Through a joint } \\
\text { association between } \\
\text { implementers of } \\
\text { village family } \\
\text { planning program } \\
\text { who were } \\
\text { previously given } \\
\text { notification letters } \\
\text { and reports on the } \\
\text { implementation of } \\
\text { activities. } \\
\text { Communication } \\
\text { between } \\
\text { implementers and } \\
\text { acceptors was done } \\
\text { through direct } \\
\text { communication or } \\
\text { notification. }\end{array}$ & $\begin{array}{l}\text { Clarify the } \\
\text { tasks and } \\
\text { functions of } \\
\text { each, } \\
\text { creating } \\
\text { clear and } \\
\text { orderly } \\
\text { coordination } \\
\text {. For } \\
\text { contraceptio } \\
\text { n acceptor } \\
\text { participants } \\
\text { further } \\
\text { socialization } \\
\text { will be held }\end{array}$ \\
\hline $\begin{array}{l}\text { Clarity of } \\
\text { Communic } \\
\text { ation }\end{array}$ & $\begin{array}{l}\text { The communication } \\
\text { obtained from the } \\
\text { government united } \\
\text { the related agencies } \\
\text { namely the health } \\
\text { department with the } \\
\text { population } \\
\text { department }\end{array}$ & $\begin{array}{l}\text { Lack of } \\
\text { coordination }\end{array}$ \\
\hline $\begin{array}{l}\text { Communic } \\
\text { ation } \\
\text { Consistenc } \\
\text { y }\end{array}$ & $\begin{array}{l}\text { Consistent, there } \\
\text { were no changes to } \\
\text { the instructions and } \\
\text { rules in the } \\
\text { implementation of } \\
\text { the program }\end{array}$ & $\begin{array}{l}\text { Creating a } \\
\text { perception } \\
\text { of equality } \\
\text { between } \\
\text { implementer } \\
\text { s }\end{array}$ \\
\hline
\end{tabular}

d. Disposition

Disposition is a factor that comes from within each program implementer in the form of the willingness to carry out their duties and obligations in carrying out the program as best as possible following agreed on guidelines. If the implementor has a pleasant disposition, then he will be able to run the policy well. However, when implementing policies have different attitudes, the process of undergoing policies was also less effective. ${ }^{[10]}$ Willingness is influenced by three elements, i.e. cognition of policy, the response to policy, and intensity of response to the policy. If these three things show a positive direction, then the level of desire to undergo the policy will increase ${ }^{[11]}$.
"The ones responsible morally were all of us, the Health Centre assisted the sub-district office as the regional authority, the daily implementation of the PLKB. The facility was not yet optimal because the RPTRA was still in a limited corridor because the particular room for medically was not yet complete. Counselling for contraception can be done in conjunction with activities at posyandu or particular events. When there was an update about contraception, it must be delivered in the RPTRA" (IU. 1)

"Disposition will be achieved if the implementers have clear and adequate knowledge and understanding regarding the content, purpose and objectives of the implementation of the village family planning program. They understood that this program is beneficiary in helping government efforts to improve the quality of the population through the participation of families, communities, the role of government, non-governmental institutions and the private sector in implementing programs" (IU. 2)

"Our response was very supportive and happy to be able to contribute to this program because this program was aimed at the welfare of the community and we were trying to work well so that this program can also run well and optimal. If this program is successful, we will also feel its welfare" (IU. 3)

"We know from the PLKB instructed to mobilize the community; for example, there would be counselling or other programs. About the disposition of our superiors, we were not fully understood" (IU. 4)

Based on the intervie result, the detailed findings of this study can be seen in Table 4.

Table 4 Research Findings on Disposition

\begin{tabular}{cll}
\hline Indicators & \multicolumn{1}{c}{ Implementation } & \multicolumn{1}{c}{ Impact } \\
\hline Knowledge & $\begin{array}{l}\text { The implementer } \\
\text { understood the }\end{array}$ & $\begin{array}{l}\text { Generate } \\
\text { positive } \\
\text { response and }\end{array}$ \\
\hline
\end{tabular}




\begin{tabular}{lll}
\hline & $\begin{array}{l}\text { purpose of the } \\
\text { program }\end{array}$ & $\begin{array}{l}\text { support for } \\
\text { program } \\
\text { implementatio } \\
\mathrm{n}\end{array}$ \\
\hline \multirow{2}{\text{Implementers}}{ Comitment } & $\begin{array}{l}\text { Have a high } \\
\text { enough } \\
\text { commitment, } \\
\text { responsible and } \\
\text { obedient to the task optimally }\end{array}$ & $\begin{array}{l}\text { Program } \\
\text { implementatio } \\
\text { n can be } \\
\text { realized } \\
\text { of }\end{array}$ \\
\hline
\end{tabular}

The executing officer of the Village Family Planning had a reasonably high disposition in terms of the knowledge and understanding of the program, and the commitment was given to the program implementation. The disposition was realized by the presence of implementers who have clear and adequate knowledge and understanding of the contents, purpose and objectives of the implementation of the Village Family Planning program. ${ }^{[12]}$ They understood that this program could be beneficiary to improve the quality of the population through family participation, the role the government, non-government organizations in carrying out the KKBPK program. The benefits arising from the emergence of positive assessment and support from staff towards the implementation of the program. The high level of support was also caused by the implementation of the program, which had been running quite effectively, smoothly, and there were no obstacles for the program implementers. This positive attitude is what drives the implementers' awareness to be able to carry out their respective duties and functions, with compliance and responsibility in providing services in family planning programs. ${ }^{[13]}$

\section{Conclusion}

The implementation of the Village Family Planning Program consists of 4 indicators, i.e., communication that the transmission was carried out with an effort to disseminate information that was not fully understood by the community. The bureaucratic structure of implementing the program and the targets of the program were optimal. Inadequate facility resources because RPTRA was still in a limited corridor because the particular room for medical treatment was incomplete. There were already an effective fragmentation and SOP that is in line with the role of the implementing task. The disposition, there was enough implementer in the program. The development of significant population growth can be seen from the increase in the number of LARC's acceptors. In the continuation of this program, there were obstacles to implementation including internal factors, namely lack of socialization about the program, especially in the prevention of 4T (4 Too) from the government to the implementers because there was no allocation in the budget. While the external factors from lack of participation and not optimal public awareness in participating.

In the implementation, facilities and infrastructure facilities such as the Village Family Planning should be made only for activities related to the program and the process of conducting the BKKBN socialization should be able to motivate the community so that they can participate in the implementation of the Village Family Planning program in RPTRA Ciracas Prima.

\section{Acknoweledgement}

Thank you to the Head of Midwifery Diploma III Study Program Mohammad Husni Thamrin, Head of LPPM, RPTRA Ciracas Prima East Jakarta, and all those who have helped in helping this research.

\section{References}

[1] BKKBN. Kebijakan dan Strategi Akselerasi Program Kependudukan $\quad K B, \quad$ dan Pembangunan Keluarga TA. 2014. Jakarta : BKKBN. 2014.

[2] Miftah, Toha. Kepemimpinan dalam Manajemen. Jakarta : PT. Raja Grafindo Persada. 2013.

[3] Isnawati. Difusi Inovasi Program Keluarga Berencana "Dua Anak Lebih Baik" dalam Mengendalikan 
Pertumbuhan Penduduk Desa

Lompio Kecamatan Sirenja

Kabupaten Donggala. Jurnal

Online Kinesik ; 2017:Volume 4

Nomor 1.

[4] Setiawati Elsa.Persepsi

Masyarakat Terhadap Program

Kampung Keluarga Berencana di

Kelurahan Pantolan Boya

Kecamatan Taweli. E- Journal

Geo-Tadulako UNTAD ; 2017

[5] Subarsono, AG. Analisis

Kebijakan Publik. Yogyakarta : Pustaka Pelajar. 2010.

[6] Wahab, Solichin Abdul. Analisis

Kebijakan: dari Formulasi

Penyusunan Model-Model

Implementasi Kebijakan Publik.

Jakarta: PT Bumi Aksara. 2012.

[7] Agustino, Leo. Dasar-dasar Kebijakan Publik.CV. Alfabeta. Jakarta. 2012.

[8] Moleong, Lexy J. Metodologi Peneltian Kualitatif. Bandung: PT Remaja Rosdakarya. 2013.

[9] Mulyadi, Deddy. Studi Kebijakan Publk Pelayanan Publik, Konsep, Aplikasi Proses Kebijakan Publik Berbasis Analisis Bukti Pelayanan Publik. Bandung: Alfabeta. 2016.

[10] Arikunto, Suharsimi. Prosedur Penelitian Suatu Pendekatan Praktik. Jakarta: Rineka Cipta. 2010.

[11] Nugroho, Riant. Public Policy. Jakarta: Elex Media Komputindo. 2014.

[12] Pasolong, Harbani. Teori Admnistrasi Publik. Bandung: Alfabeta. 2011.

[13] Suaib, Muhammad Ridha. Pengantar Kebijakan Publik AdministrasiNegara, Kebijakan Publik, Administrasi Publik, Pelayanan Publik, Good Governance, Implementasi Kebijakan Publik. Yogyakarta: Calpulis. 2016. 